Gut, 1972, 13, 718-720

\title{
Levels of salivary IgA in treated and untreated coeliac disease
}

\author{
T. WAllington, A. B. AJDUKiEWICZ, A. E. READ, AND J. VERRIER JONES \\ From the Department of Medicine, Bristol Royal Infirmary
}

SUMMARY Estimations of the concentration of secretory IgA have been performed on 152 specimens of saliva from 46 patients with adult coeliac disease. The results are compared with values observed in 20 normal subjects. The mean salivary IgA concentration was $9 \mathrm{mg} \%$ in 36 patients on a normal diet and $7.9 \mathrm{mg} \%$ in 21 patients on a gluten-free diet. In 20 normals the mean salivary IgA was $7 \cdot 1 \mathrm{mg} \%$. Nine patients were studied before and after gluten exclusion. Seven of these showed a marked fall in salivary $\operatorname{IgA}$ concentration after gluten was excluded.

The lymphoreticular responsiveness and serum immunoglobulins of patients with coeliac disease have been studied intensively over the past four years. Eidelman, Davis, Lagunoff, and Rubin (1966) studied the serum IgA in 21 normal subjects, six patients with coeliac disease and five patients with hypogammaglobulinaemia, and found significantly increased concentrations in coeliac disease. Hobbs and Hepner (1968) studied 75 adults and five children with coeliac disease and found their serum $\operatorname{IgA}$ and IgG levels to be largely within the normal range$61 \%$ of the untreated patients had decreased IgM concentrations compared with only $6 \%$ of the treated patients. In 16 of 18 patients who had gluten withdrawn from their diet the serum IgM increased to within the normal range. Blecher, BrzechwaAjdukiewicz, McCarthy, and Read (1969) studied 30 untreated patients and found that 11 had a low serum IgM concentration, 11 had increased serum IgG concentrations, and eight had raised serum IgA concentrations. Asquith, Thompson, and Cook (1969) studied 110 patients with coeliac disease and 152 controls, and found in general that in coeliac disease the serum IgM and IgG concentrations were decreased. The serum IgA concentrations were high, and returned towards normal with gluten exclusion. Kenrick and Walker-Smith (1970) found high serum IgA concentrations in eight out of 24 children with coeliac disease. In four of these the concentration returned to normal when gluten was excluded. Considering overall measurements of serum immunoglobulins there is little consistency in these results, though they do suggest that coeliac disease is associated with disturbances of humoral immunity.

Since the main changes in coeliac disease are seen

Roceived for publication 30 May 1972. in the gut, we have attempted to study these more directly by measuring the levels of secretory $\operatorname{IgA}$ in the saliva of treated and untreated patients with coeliac disease. We elected to study IgA levels in unstimulated mixed saliva. Brandtzaeg, Fjellanger, and Gjeruldsen (1970) showed that, although measurements of forced parotid saliva show a narrower range of normal values, unstimulated whole saliva contains a high IgA concentration with a wider but proportionately similar range of normal values.

Untreated patients were found to have a higher concentration of salivary $\operatorname{IgA}$ than patients treated with a gluten-free diet, who were similar to controls. The majority of patients showed a fall in salivary IgA concentrations following the withdrawal of gluten from the diet.

\section{Materials and Methods}

Samples of saliva were obtained from 40 patients with adult coeliac disease. Serial specimens were collected over a period of 18 months in 26 of these patients. All patients had subtotal villous atrophy of their jejunal mucosa. During the study 28 patients were on a normal diet and 21 on a gluten-free diet. Nine were studied both before and after gluten withdrawal. Control samples were obtained from 21 healthy subjects.

Samples of saliva were collected by a standard method. Patients were asked to wash out their mouths with water, wait for a few minutes, and then collect saliva as it formed for 10 minutes. Preliminary experiments showed that any attempt to accelerate the flow of saliva distorted the results. Samples were stored at $-20^{\circ} \mathrm{C}$ until testing. 
Secretory IgA concentrations were determined by the method of electroimmunodiffusion (Merrill, Hartley, and Claman, 1967). Standard solutions of secretory IgA were prepared from a large pool of normal saliva, which was quantitated in Dr Merrill's laboratory. Antiserum was prepared in rabbits to human colostral secretory IgA. Replicates of the same sample were examined on each plate and the results varied by not more than $5 \%$. The value for each sample is the mean of three separate determinations.

\section{Results}

Seventy-five specimens of saliva from patients with coeliac disease on a gluten-free diet, 77 specimens from patients on a normal diet, and 34 specimens from healthy control subjects were examined. Of these specimens, 141 had been collected sequentially in 26 patients and two controls. The values for $\mathrm{IgA}$ in sequential specimens from an individual were found to be constant to within $\pm 2 \mathrm{mg} \%$. For comparison the mean of serial values for each subject and the standard deviation for the normal group were calculated. Figure 1 shows the mean values. Patients with untreated coeliac disease had a mean salivary IgA concentration of $9 \mathrm{mg} \%$. The mean for dieted patients was $7.9 \mathrm{mg} \%$ and for controls $7.1 \mathrm{mg} \%$. The range of concentrations in the non-dieted group was greater than in the dieted, and in particular patients with high secretion of IgA are better represented in this group, with two having concentrations more than 2 standard deviations above the mean for the group. Although the figures for coeliac patients show a skew distribution, there is no evidence for a departure from normal distribution in the control subjects. Our figures for patients are too low to determine whether we are studying a logarithmic distribution or two separate groups of patients.

Sequential specimens from an individual changed markedly when they exchanged a normal diet for gluten restriction. Figure 2 shows the serial salivary secretory IgA concentrations of all patients who changed their diet during the course of the study. The shaded area shows the mean \pm 2 standard deviations for the salivary secretory IgA in a normal population. Before gluten was excluded all but one of the patients secreted salivary IgA above this range. Exclusion of gluten brought all levels of IgA quickly to within the normal range.

\section{Discussion}

In adults with untreated coeliac disease the mean salivary IgA concentration was higher than in those treated with a gluten-free diet. There is a skew in the distribution of values in these groups and in particular patients with a high secretion of IgA are better represented in the untreated group. Comparison of Figs. 1 and 2 shows that patients in the untreated

\section{SALIVARY IgA}

( mean \pm 2 S.D. $)$

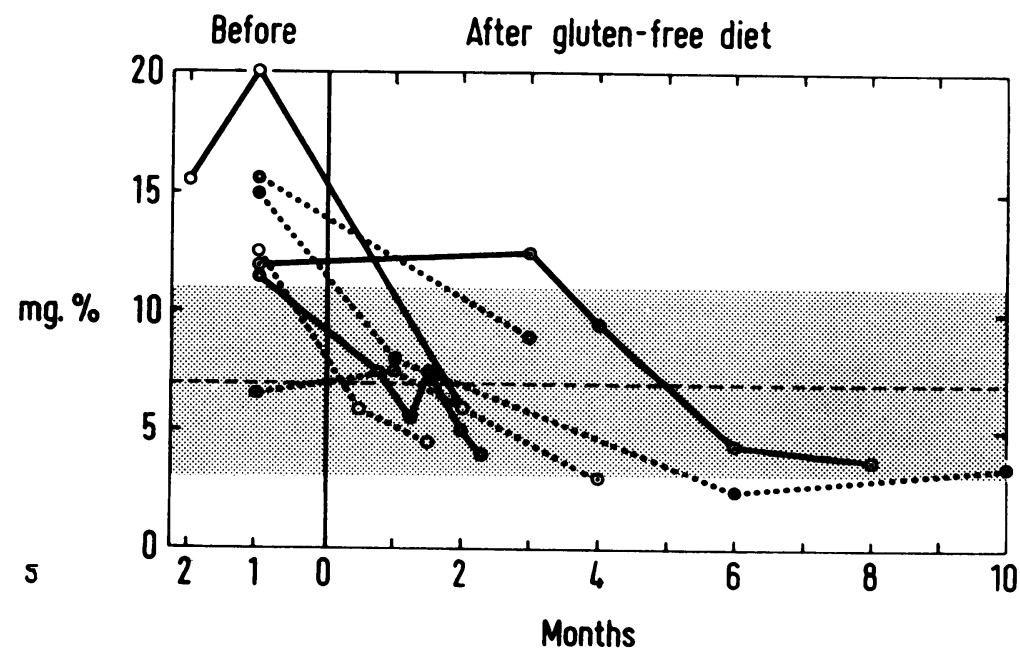

Fig. 1 Mean values of serial measurements of salivary $\operatorname{IgA}$ in controls, patients not treated with a gluten-free diet, and patients after withdrawal of gluten from their diet. 


\section{SALIVARY IgA}

$($ mean \pm 2 S.D. $)$

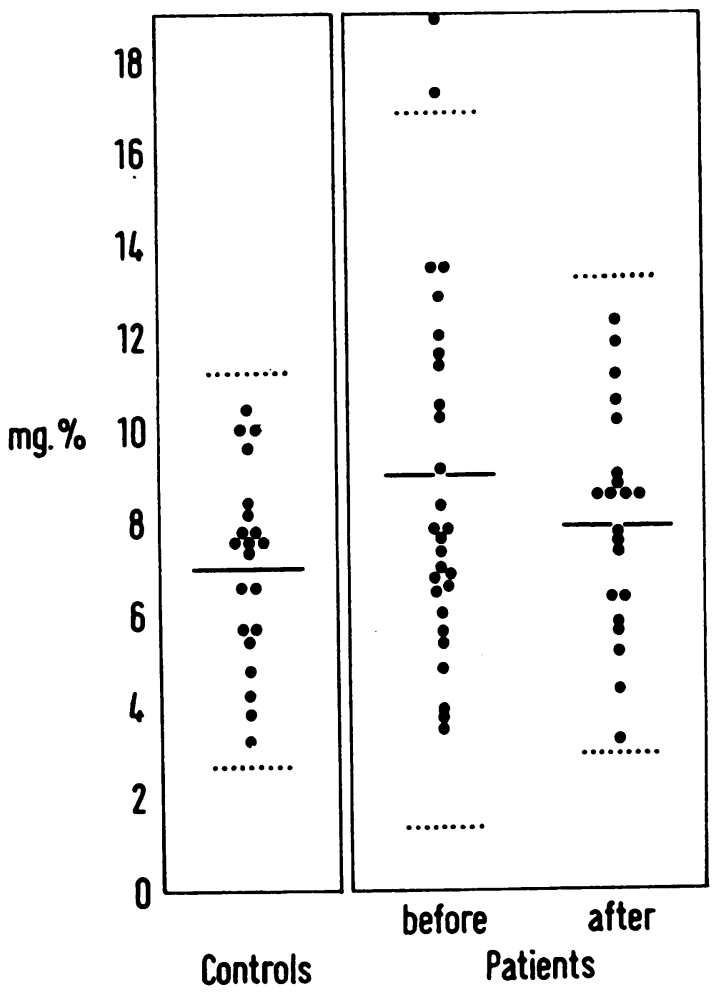

Fig. 2 Serial salivary IgA concentrations in patients proceeding to treatment with a gluten-free diet.

group who became ill enough to need gluten exclusion are particularly well represented amongst those with a high salivary IgA concentration. There were nine in all of these and seven of them showed a marked fall in salivary IgA when gluten was removed from their diet.

There have been a few reported measurements of salivary IgA in patients with coeliac disease. Douglas, Crabbé, and Hobbs (1970), in an extensive report of immunochemical studies in coeliac disease, found no abnormality in coeliac salivary $\operatorname{IgA}$ and no change with gluten restriction. It should be noted, however, that they used a less sensitive method for IgA measurement, and that their range for normal ( 3 to $30 \mathrm{mg} \%$ was much greater than ours and that of Merrill and her colleagues (Claman, Merrill, and Hartley, 1967) (3 to $11 \mathrm{mg} \%$ ) who used electroimmunodiffusion.
What is the significance of the high IgA levels in untreated patients? An immunofluorescent study of the plasma cells of the small gut of patients with coeliac disease suggested that IgA-producing cells were increased (Rubin, Fauci, Sleisenger, and Jeffries, 1965). The work of Crabbé and Heremans (1966) with patients suffering from IgA deficiency and coeliac disease showed that the major immunoglobulin produced by the intestinal plasma cells was IgM. Douglas et al (1970) suggested that IgAproducing cells were present in normal numbers in coeliac disease and that the intestinal plasma cells were mainly producing IgM. This conclusion is supported by their immunoglobulin measurements in jejunal juice. In general there appears to be an increased plasma cell population in the gut lining in coeliac disease. Our observations suggest that increased immunological activity within the salivary glands is also a common finding in coeliac disease.

We are grateful to Dr Deborah Merrill for help with the technique of electroimmunodiffusion and for estimating the secretory IgA in a standard pool of saliva.

Financial assistance was provided by a grant from the Medical Research Committee of the United Bristol Hospitals.

\section{References}

Asquith, P., Thompson, R. A., and Cooke, W. T. (1969). Serumimmunoglobulins in adult coeliac disease. Lancet, 2, 129-131.

Blecher, T. E., Ajdukiewicz, A. B., McCarthy, C. F., and Read, A. E. (1969). Serum immunoglobulins and lymphocyte transformation studies in coeliac disease. Gut, 10, 57-62.

Brandtzaeg, P., Fjellanger, I., and Gjeruldsen, S. T. (1970). Human secretory immunoglobulins. 1. Salivary secretions from individuals with normal or low levels of serum immunoglobulins. Scand. J. Haemat., Suppl., 12.

Claman, H. N., Merrill, D. A., and Hartley, T. F. (1967). Salivary immunoglobulins: normal adult values and dissociation between serum and salivary levels. $J$. Allergy, 40, 151-159.

Crabbé, P. A., and Heremans, J. F. (1966). Lack of gamma Aimmunoglobulin in serum of patients with steatorrhoea. Gut, 7, 119-127.

Douglas, A. P., Crabbé, P. A., and Hobbs, J. R. (1970). Immunochemical studies of the serum, intestinal secretions and intestinal mucosa in patients with adult celiac disease and other forms of the coeliac syndrome. Gastroenterology, 59, 414-425.

Eidelman, S., Davis, S. D., Lagunoff, D., and Rubin, C. E. (1966). The relationship between intestinal plasma cells and serum immunoglobulins in man. (Abstr.) J. clin. Invest, 45, 1003-1004.

Hobbs, J. R., and Hepner, G. W. (1968). Deficiency of $\gamma$ M-globulin in coeliac disease. Lancet, $1,217-220$.

Kenrick, K. G., and Walker-Smith, J. A. (1970). Immunoglobulins and dietary protein antibodies in childhood coeliac disease. Gut, 11, 635-640.

Merrill, D., Hartley, T. F., and Claman, H. N. (1967). Electroimmunodiffusion (EID): a simple rapid method for quantitation of immunoglobulins in dilute biological fluids. J. Lab. clin. Med., 69, 151-159.

Rubin, W., Fauci, A. S., Sleisenger, M. H., and Jeffiries, G. H. (1965). Immunofluorescent studies in adult celiac disease. J. clin. Invest., 44, 475-485. 